\title{
Evaluation of Mungbean Genotype for Resistance against Black Aphid (Apis craccivora Koch.) under Terai Agro Ecological System of West Bengal
}

\author{
Sagar Tamang, Umesh Das ${ }^{*}$, Tanuj Debbarma and Sandeep Mandal
}

Department of Agricultural Entomology, Uttar Banga Krishi Viswavidyalaya, Cooch Behar, West Bengal-736165, India

*Corresponding author

India is the largest producer and consumer of pulses in the world accounting for 33 per cent of world area and 22 per cent of world production. At present, in India, the total area under pulses is $24.45 \mathrm{~m}$ ha with a total production of $15.24 \mathrm{mt}$ and the average productivity is $623 \mathrm{~kg}$ per ha (Masood Ali and Shivakumar, 2004). Aphids are an important group of insects with worldwide distribution. The sap sucking aphids (A. craccivora) cause significant damage to the crop and is reported as one of the important, major and economic pest of mung bean, cowpea and other legumes. At present day, management of insect pest has largely been relied on chemical control. However, the demands for clean and ecologically sound control envisages, careful planning for rationalizing the insecticides interventions. Development of resistant varieties is an ideal component against buildup of pest population at no additional cost, compatible with other methods of pest control and free from control pollution.

The field experiments were conducted in the agriculture research field at UBKV, Pundibari, Cooch Behar and West Bengal during the year 2012-13. Five varieties, (Sonali (B-1)), Bireswar (WBM-4-34-1-1), Samrat (PDM 24-
139), Sukumar (WBM-29) and Panna (B-105) commonly cultivated in this region were selected for evaluations against aphid of moong. The seeds were sown in a plot size of $2 \mathrm{~m} \times 3 \mathrm{~m}$ with the spacing of $20 \mathrm{~cm} \times 40 \mathrm{~cm}$, in RBD. Ten plants were selected from each plot randomly and one or two branches per plant were taken for the tagging. Weekly observation of aphids on each of the tagged branch was taken in per $10 \mathrm{~cm}$ twigat regular intervals. In case of lady bird beetle were recorded in number of plant basis after appearance of the pest till harvest of the crop.

During first season, among the five test genotypes, Mungbean variety Bireswar (WBM-34-1-1) had significantly lowest number $(1.12 / 10 \mathrm{~cm}$ twig) of aphid population as compared to the other tested varieties. Variety Sukumar (WBM-29) with 1.35 number aphids per $10 \mathrm{~cm}$ twig ranked second in its resistance. Variety Panna (B105) Sonali (B-1) and Samrat (PDM 24-139) with $3.13,3.26$ and 5.30 aphid/10 cm twig, respectively, showed susceptibility to aphids as compared to Bireswar (WBM-34-1-1) and Sukumar (WBM-29).

The last before mentioned two susceptible 
varieties were not significantly different to each other in the per $10 \mathrm{~cm}$ twig aphid population. Highest (2.20/ plant) predatory coccinellid beetle was observed on Bireswar (WBM-34-1-1) followed by Sonali (B-1) and Samrat (PDM 24-139) with 1.89 and 1.25 numbers per plant, respectively. Lowest (0.84/ plant) lady beetle was observed on Panna (B105) variety. Comparing the yield production, mungbean variety Bireswar (WBM-34-1-1) with $558.79 \mathrm{~kg} / \mathrm{ha}$ ranked first followed by Sukumar (WBM-29), Samrat (PDM 24-139), Sonali (B-1) and Panna (B-105) with 547.47, $418.83,405.84$ and $392.79 \mathrm{~kg} / \mathrm{ha}$, respectively. The high yield of Bireswar (WBM-34-1-1) and Sukumar (WBM-29) was mainly attributed to the low attack of sucking insect pests because of their resistant abilities.

These results are in accordance with the results of previous workers like Naqvi et al., (1995) has tested 10 genotypes of mungbean against aphid and found only two cultivars, M8-20 and M-1030 resistant against aphid compared to others. On the basis of results, it can be concluded that variety Bireswar (WBM-34-1-1) had less susceptibility to the attack of aphid, gave highest grain yield followed by Sukumar (WBM-29) during first season. During second season, among the five test genotypes, highest $(6.25 / 10 \mathrm{~cm}$ twig) aphid incidence was recorded on Samrat (PDM 24-139) followed by Panna (B-105) and Sonali (B-1) with 5.75 and 4.94 numbers per $10 \mathrm{~cm}$ twig, respectively. Lowest $(1.76 / 10 \mathrm{~cm}$ twig) aphid infestation was observed in the Bireswar (WBM-34-1-1) variety.

Highest (4.17/plant) predatory coccinellid beetle was observed on Sukumar (WBM-29) followed by Sonali (B-1) and Samrat (PDM 24-139) with 2.59 and 1.95 numbers per plant, respectively. Lowest $(0.88 /$ plant $)$ lady beetle was observed on Panna (B-105) variety. In varietal evaluation it was prove that Bireswar (WBM-34-1-1) and Sukumar (WBM-29) were fairly resistant to aphid of moong. Beside this variety, remaining were neither fully resistant. Samrat (PDM 24-139) was heavily infested by aphid, which gave poor yield (Table 1).

Table.1 Evaluation of Moong varieties against aphids and coccinellid during $1^{\text {st }} \& 2^{\text {nd }}$ season

\begin{tabular}{|c|c|c|c|c|c|c|}
\hline \multirow[b]{2}{*}{ Varieties } & \multicolumn{3}{|c|}{$1^{1 \mathrm{st}}$ season } & \multicolumn{3}{|c|}{$2^{\text {nd }}$ season } \\
\hline & $\begin{array}{c}\text { Aphid/ } 10 \\
\text { cm twig }\end{array}$ & $\begin{array}{l}\text { Coccinellid/ } \\
\text { plant }\end{array}$ & $\begin{array}{c}\text { Yield } \\
\text { (kg/ha) }\end{array}$ & $\begin{array}{c}\text { Aphid/ } 10 \\
\text { cm twig }\end{array}$ & $\begin{array}{l}\text { Coccinellid/ } \\
\text { plant }\end{array}$ & $\begin{array}{c}\text { Yield } \\
\text { (kg/ha) }\end{array}$ \\
\hline Sonali & $\begin{array}{c}3.26 \\
(1.93)^{*}\end{array}$ & $\begin{array}{c}1.89 \\
(1.54)^{*}\end{array}$ & 405.84 & $\begin{array}{c}4.94 \\
(2.29)\end{array}$ & $\begin{array}{c}2.59 \\
(1.73)\end{array}$ & 896.50 \\
\hline Bireswar & $\begin{array}{c}1.12 \\
(1.26)\end{array}$ & $\begin{array}{c}2.20 \\
(1.60)\end{array}$ & 558.19 & $\begin{array}{c}1.76 \\
(1.49)\end{array}$ & $\begin{array}{c}1.40 \\
(1.36)\end{array}$ & 1108.25 \\
\hline Samrat & $\begin{array}{c}5.30 \\
(2.39)\end{array}$ & $\begin{array}{c}1.25 \\
(1.30)\end{array}$ & 418.83 & $\begin{array}{c}6.25 \\
(2.57)\end{array}$ & $\begin{array}{c}1.95 \\
(1.54)\end{array}$ & 902.31 \\
\hline Sukumar & $\begin{array}{c}1.35 \\
(1.38)\end{array}$ & $\begin{array}{c}1.08 \\
(1.23)\end{array}$ & 547.47 & $\begin{array}{c}1.86 \\
(1.53)\end{array}$ & $\begin{array}{l}4.17 \\
(2.13)\end{array}$ & 1052.75 \\
\hline Panna & $\begin{array}{c}3.13 \\
(1.87)\end{array}$ & $\begin{array}{c}0.84 \\
(1.14)\end{array}$ & 392.79 & $\begin{array}{c}5.75 \\
(2.48)\end{array}$ & $\begin{array}{c}0.88 \\
(1.15)\end{array}$ & 883.79 \\
\hline SE $m \pm$ & 0.147 & 0.434 & 38.80 & 0.532 & 0.505 & 48.25 \\
\hline $\mathrm{CD}(\mathrm{p}=0.05)$ & 0.453 & 0.141 & 119.56 & 0.172 & 0.164 & 148.68 \\
\hline
\end{tabular}


Among the cultivars, the highest (1108.25 $\mathrm{kg} / \mathrm{ha}$ ) yield potential was obtained in Bireswar (WBM-4-34-1-1) followed by Sukumar (WBM-29) with grain yield of $1052.75 \mathrm{~kg} / \mathrm{ha}$ during second season were mainly attributed to the low attack of sucking insect pests because of their resistant abilities.

Whereas, the results of the present findings lead towards a conclusion that among the tested cultivars, Bireswar (WBM- 34-1-1) and Sukumar (WBM-29) showed comparatively better resistant cultivars regarding low mean population of aphid as compared to other tested varieties. Bireswar (WBM-34-1- 1) was found least affected by aphid and gave the higher yield followed by Sukumar (WBM-29) while the cultivar, Samrat was heavily infested by aphid.

\section{References}

Masood Ali and Shivakumar, (2004) Pulse production in India.The Hindu Survey of Indian Agriculture, Pp. 37-43.

Naqvi, S. H., Talpur, M.A., Khan, Rustamani, Mand, M. and Hussain, T. (1995). Relative resistance of mungbean [Vigna radiata (L.)Wilczek], varieties to whitefly and yellow mosaic virus. Proceed. XIV Pak. Cong. Zool., Islamabad, Pakistan, 15: 247-251.

\section{How to cite this article:}

Sagar Tamang, Umesh Das, Tanuj Debbarma and Sandeep Mandal. 2018. Evaluation of Mungbean Genotype for Resistance against Black Aphid (Apis craccivora Koch.) under Terai Agro Ecological System of West Bengal. Int.J.Curr.Microbiol.App.Sci. 7(09): 1783-1785. doi: https://doi.org/10.20546/ijcmas.2018.709.215 